Article

\title{
Ownership by Mutual Funds and Corporate Reporting of Environmental Responsibility: Empirical Evidence from China 2007-2019
}

\author{
Yi Luo ${ }^{1,2}$, Lijun $\mathrm{Lu}^{2,3, *}$ and Shu Lin ${ }^{2, *}$ \\ 1 School of Accounting, Guizhou University of Finance and Economics, Guiyang 550025, China; \\ luoyi@smail.nju.edu.cn \\ 2 Business School, Nanjing University, Nanjing 210093, China \\ 3 School of Accounting, Wuxi Taihu University, Wuxi 214063, China \\ * Correspondence: lulijun@smail.nju.edu.cn (L.L.); slin@nju.edu.cn (S.L.)
}

Citation: Luo, Y.; Lu, L.; Lin, S. Ownership by Mutual Funds and Corporate Reporting of

Environmental Responsibility: Empirical Evidence from China 2007-2019. Sustainability 2021, 13, 11527. https://doi.org/10.3390/ su132011527

Academic Editor: Giuliana Birindelli

Received: 28 July 2021

Accepted: 7 September 2021

Published: 19 October 2021

Publisher's Note: MDPI stays neutral with regard to jurisdictional claims in published maps and institutional affiliations.

Copyright: (c) 2021 by the authors. Licensee MDPI, Basel, Switzerland. This article is an open access article distributed under the terms and conditions of the Creative Commons Attribution (CC BY) license (https:// creativecommons.org/licenses/by/ $4.0 /)$.

\begin{abstract}
After 40 years of economic ascendancy, China's environmental challenges and public awareness of them have swelled substantially. Both concern mutual funds that invest in publicly traded Chinese firms, many of which have shown questionable environmental responsibility. This study investigates whether mutual fund ownership of Chinese corporations influences firms' disclosures of environmental responsibility by empirical methodologies. Annual data for 25,188 firm-year observations of corporations trading as A-shares in Shanghai and Shenzhen from 2007-2019 revealed that ownership by mutual funds, and especially by leading funds, correlates strongly and positively with environmental disclosures. These results imply that mutual funds were activist investors that influenced sampled firms to disclose their environmental responsibility during the period 20072019. We also examine environmental reporting and mutual fund stock ownership in relation to security analyst coverage, whether sampled firms are government-owned, and periods before and after the implementation of China's New Environmental Protection Law. Results are heterogeneous with respect to all three considerations. Our findings are significant for regulators, investors, and corporate managers.
\end{abstract}

Keywords: environmental awareness; shareholder activism; mutual fund; listed company; supervisory role

\section{Introduction}

In recent years, Chinese companies have committed a series of environmentally damaging acts, including water pollution by Zijin Mining, illegal disposal of hazardous waste by Bohui Study, and ubiquitous dumping of sludge by other companies. From June 2012 to June 2020, reports show 19,770 infractions of social and corporate governance involving 1293 listed Chinese companies, of which 8447 (43\%) entailed environmental damage. These infractions occasioned losses to investors, notably mutual funds that held their stocks. According to China Fund Industry Responsible Investment Surveys in 2013 and 2014, nearly $80 \%$ of mutual fund companies incurred losses from the Zijin incident, after which they started integrating indicators of environmental responsibility into their investing criteria.

Because mutual fund companies are a force in Chinese financial markets, their attention to firms' social and environmental responsibility compelled listed companies to respond. Chen et al. [1] found that funds intervene in corporate decisions through voting rights. Firth et al. [2] found that funds' activist influence is strong when the proportion of fund holdings is high. Cox and Wicks [3] assert that long-term institutional investors exercise shareholder oversight to improve information disclosure. Njah and Jarboui [4] found that institutional investors intervene to inhibit "managed" earnings. 
In 2020, such global challenges as the corona virus, climate change, and depletion of natural resources forced countries to monitor corporate activities [5]. The integration of environmental responsibility into monitoring is now the consensus position of regulators and market participants. Although environmental responsibility is non-financial information, it bears value [6]. It can offer companies competitive advantage [7] and improve both performance [8] and the quality of financial reporting [9].

Numerous studies have investigated factors that influence environmental disclosure. Darnall et al. [10] relate it to the legal and regulatory regimes of countries where firms locate. Social and political pressures underlie disclosure of environmental responsibility. Clarkson et al. [11], Liu and Anbumozhi [12], Zeng et al. [13], and Gray et al. [14] associate large and more profitable companies with greater environmental disclosure. The attributes of a company's industry drive voluntary environmental disclosure [15]. Liu and Anbumozhi [12] found that transitioning from planned to market economies correlates positively with corporate disclosures of environmental responsibility. Kock et al. [16] showed that corporate governance structures influence senior managements' disclosure of information in relation to environmental responsibility. Kumar et al. [17] reviewed the influential journal, Business Strategy and the Environment (BSE), which is committed to interdisciplinary research and the promotion of business practices to improve environmental performance and contributes to business strategy and sustainability. China is one of the top three countries contributing to BSE.

Although research has examined mutual funds as monitoring and governance entities, no prior study correlates A-listed Chinese firms' disclosure of environmental responsibility with mutual fund ownership of their stock. This study fills that void in the literature.

This study relates stock ownership by mutual funds to firms' environmental reporting. Based on 25,188 annual firm-year observations of A-share listed companies on two Chinese stock exchanges from 2007 to 2019, we find that the larger the proportion of a firm's outstanding shares held by mutual funds, the greater is a firms' motivation to report their environmental responsibility. The greater the proportion of leading mutual funds among firms' shareholders, the more likely that the surveyed firms would disclose information concerning environmental responsibility.

This study also examines environmental reporting and mutual fund stock ownership in relation to security analyst coverage, whether firms are government-owned, and periods before and after implementation of China's New Environmental Protection Law. Results are heterogeneous with respect to all three considerations.

This study makes two contributions to the literature. First, it adds to the understanding of factors that underlie corporate disclosure of environmental responsibility. Second, results imply that mutual funds as activist investors influence firms' disclosure of environmental responsibility and firms' commitment to environmental responsibility itself. Our findings are relevant for regulators, investors, and corporate managers. In particular, they show regulators the importance of leveraging mutual funds' influence on environmental responsibility in meeting their public mission, and they demonstrate, for corporate managers, the importance of disclosing their responsibilities toward the environment.

This study proceeds as follows. Section 2 develops hypotheses in light of previous research and theory. Section 3 describes our research design, including sample selection, model specification, and variable measurements. Section 4 presents and discusses the empirical results. Section 5 concludes.

\section{Hypothesis Development}

Shareholder activism originated in the United States during the 1980s and intensified during the 1990s as institutional investors came to own more than $50 \%$ of the shares of major publicly traded U.S. companies [18]. Shareholder activism entails shareholders using their voting power to involve themselves in numerous aspects of corporate governance [19]. Institutional investors have influenced the governance of listed companies $[17,20,21]$. Alshabibi [22] studies the role of institutional investors in the improvement of corporate 
governance and found that the activism of shareholders is contingent on the institutional settings. Sakawa and Watanabel [23] showed that the supervision role of institutional shareholders functions effectively in Japanese companies.

Morck et al. [24] found that mutual funds serve their long-term interests by exercising oversight of listed companies, and their motivation to do so increases with the proportion of a firm's shares that they own. Ownership by mutual funds influences companies' governance, responses to social and political issues [25], and acceptance of corporate social responsibility [26-28]. Chung and Talaulicar [29] found that mutual funds push their invested companies toward social responsibility, and thereby, firms build reputations that enhance their ability to attract investment and enhance returns.

Although disclosure of environmental information by Chinese firms is in its nascence, listed companies must disclose it, which is an issue of rising concern for and involvement by mutual funds [30]. Pucheta-Martínez and García-Meca [31] found that low proportional shareholdings by fund-type investors dampens confidence in the dialog with listed companies, and it is difficult to establish effective constraints on listed companies. Funds that own a high proportion of a firm's outstanding shares can intervene in governance and prompt companies to disclose information that provides a more comprehensive understanding of them.

Activist mutual funds can influence other investors and stakeholders and instill a commitment to environmental responsibility that elevates a firm's profile among stakeholders, its social reputation, its sustainable advancement, and it resilience during crises [32]. From this perspective, the value of disclosing environmental information sought by mutual funds may exceed that of financial disclosures. Therefore, listed companies often perform well in environmental responsibilities, providing assurance for shareholder wealth $[7,33,34]$, which motivates mutual funds to urge firms toward environmental responsibility.

Therefore, researchers argue that leading funds are more likely to be activist investors than other funds, even if both own an equal percentages of a firm's shares. The reason for this is that leaders have the financial strength, professional capabilities, information, reputation, and market influence that firms must consider. Their opinion can raise or deflate a firm's share price and access to financing, and firms cannot dismiss their requirements for information $[35,36]$. These characteristics also make mutual funds desirable shareholders for their insight into financial, social, political, and environmental issues [1,37]. For that reason, also, firms cannot dismiss their involvement in corporate governance and reporting [38-41].

In China today, the public's awareness of environmental protection has been awakened, and the government punishes pollution and controls chaos. They notice that the impact of listed company environmental events on capital markets must be strictly supervised in order to prevent portfolios losses. Therefore, only leading mutual funds can maintain a good reputation in the industry and continue to win the favor of fund investors to maintain their leading position in the industry [42]. Top-level mutual fund companies are more motivated to stimulate the awareness of the environmental responsibility of listed companies they invest in, and to supervise their performance of environmental responsibilities. This influence changes with their increased right to have their say in the dealings of listed companies $[2,43]$. Specifically, the greater the voice of leading mutual funds in listed companies, the more they can urge awareness of environmental responsibility.

We propose Hypotheses 1 and 2.

Hypothesis H1. Firms are more likely to disclose information concerning environmental responsibility if mutual funds hold a greater proportion of their outstanding shares.

Hypothesis H2. Firms are more likely to disclose information concerning environmental responsibility if leading mutual funds hold a greater proportion of their outstanding shares. 


\section{Research Design}

\subsection{Sample and Data Sources}

We drew data for firms listed as A-shares on the Shanghai and Shenzhen Stock Exchanges spanning the period 2007-2019. We obtained data concerning environmental disclosures, the percentage of outstanding shares held by mutual fund, and annual data from the China Stock Market Accounting Research database. We rejected observations with missing values and Winsorized all continuous variables at $1 \%$ and $99 \%$. These restrictions yielded a usable sample of 25,188 firm-year observations.

\subsection{Variable Definitions}

Table 1 displays variables for testing Hypotheses 1 and 2.

Table 1. Definitions of Key Variables.

\begin{tabular}{|c|c|c|}
\hline Variables & Variables Name & Variable Definitions \\
\hline Dependent variable & PDERI & $\begin{array}{l}\text { Public disclosure of environmental responsibility information takes } 1,0 \\
\text { for otherwise }\end{array}$ \\
\hline \multirow{2}{*}{ Independent variable } & Total_FH & $\begin{array}{l}\text { The sum of the proportions of shares held by all mutual fund companies of } \\
\text { the listed company (decimal) }\end{array}$ \\
\hline & Top_FH & $\begin{array}{c}\text { Proportion of shares held by top mutual fund companies (top } 10 \text { in the } \\
\text { industry) of listed company shares (decimal) }\end{array}$ \\
\hline \multirow{13}{*}{ Controlled variable } & Size & $\begin{array}{c}\text { The natural logarithm of the current market value (10,000 RMB) of } \\
\text { individual stocks in the listed company }\end{array}$ \\
\hline & Lev & Long-term debt to equity ratio of listed companies in the current period \\
\hline & Roa & $\begin{array}{l}\text { The ratio of the net profit of listed company to the total beginning assets in } \\
\text { the current period }\end{array}$ \\
\hline & Loss & Loss for current period takes 1,0 for otherwise \\
\hline & Growth & Revenue growth rate for current period \\
\hline & Dual & Dual CEO-chairman role takes 1,0 for otherwise \\
\hline & Top1 & Shareholding ratio of the largest shareholder at the end of the period \\
\hline & Board & Natural logarithm of the number of board members plus 1 \\
\hline & Indep & Proportion of independent directors in the board of directors \\
\hline & Age & years of the listed company registered in the current financial period \\
\hline & Div & $\begin{array}{l}\text { The ratio of the cumulative cash dividend per share of the current listed } \\
\text { company to the stock price per share at the end of the period }\end{array}$ \\
\hline & Liquid & $\begin{array}{l}\text { The ratio of the cumulative trading volume of the listed company in the } \\
\text { current period to the market value of individual stocks }\end{array}$ \\
\hline & BTM & Book-to-market ratio in the current financial period \\
\hline
\end{tabular}

Based on Gisbert and Navallas [44], Eugene et al. [45], and Chau and Gray [46], the dependent variable in Table 1 is the sampled firms' public disclosures of information concerning environmental responsibility (PDERI). The variable receives a value of 1 if a firm has issued a public disclosure concerning its environmental responsibility and 0 otherwise. Chinese firms normally issue environmental disclosures in an omnibus report on social responsibility. Few disclose that information in a self-standing report on environmental responsibility, and if they do, it appears in the social responsibility report. Therefore, we based the dependent variable on environmental disclosures in the social responsibility reports of sampled firms.

Our two independent variables are the proportion of sampled firms' shares held by all mutual fund companies at yearend (Total_FH) and the proportion held by leading fund companies (Top_FH) at yearend. Total_FH intimates how much influence all mutual funds 
exert on the sampled firms. The greater its value, the greater is the presumed likelihood that ownership by mutual funds overall translates into influence over environmental disclosure. Leading mutual fund companies are defined as the largest 10 fund companies, measured by equity assets managed during the current year. The greater the value of Top_FH, the greater is the presumed likelihood that leading funds influence environmental disclosure.

Following Huang and Kung [47] and D'Amico et al. [48], we include as control variables the market value of the sampled companies (Size), financial leverage (Lev), return on assets (Roa), losses (Loss), income growth rate (Growth), dual role (Dual), holdings by the largest shareholder (Top1), number of directors (Board), the proportion of independent directors (Indep), company age (Age), dividends (Div), stock liquidity (Liquid), book-tomarket ratio $(B T M)$, year, industry, and other factors.

Size is the natural logarithm of the market value of outstanding common stock at year end (in RMB 10,000). Lev is the ratio of long-term liabilities to shareholder equity at yearend. Roa is net income divided by average total assets at the start of the year. Loss takes the value of 1 if the sampled firm reported a loss during the year ( 0 otherwise). Growth is the rate of growth in total operating income rate during the current year. Dual takes the value of 1 if the chief executive officer is concurrently chairman of the board ( 0 otherwise). Top1 is the proportion of outstanding common stock held by the largest shareholder at yearend. Board is the natural logarithm of the number of board members at yearend plus one. Indep is the proportion of independent directors at yearend. Age is the number of years the sampled firm had been established at the end of the financial year. Div is cumulative cash dividends per share divided by stock price per share at yearend. Liquid is cumulative trading volume during the current year divided by the firm's market value at yearend. $B T M$ is the book value of equity at yearend divided by market value.

\subsection{Research Model}

\subsubsection{Model for Hypothesis 1}

Model 1 tests Hypothesis 1.

$$
\operatorname{PDERI}_{i, t}=\beta_{0}+\beta_{1} \times \text { Total_FH }_{i, t}+\beta_{n} \times \text { Control }_{i, t}+e_{i, t} .
$$

$P D E R I_{i, t}$ takes 1 if company $i$ disclosed information concerning environmental responsibility during year $t$ ( 0 otherwise). If Total_FH $H_{i, t}$ for company $i$ rises at the end of year $t$, ownership by all mutual fund companies is presumed to exert a rising influence on environmental disclosure. Following Huang and Kung [47] and D'Amico et al. [48], Control $_{i, t}$ controls the market value of the sampled companies (Size), leverage (Lev), return on assets (Roa), loss (Loss), income growth rate (Growth), dual role integration (Dual), largest shareholder (Top1), number of board of directors (Board), proportion of independent directors (Indep), company age (Age), dividends (Div), liquidity (Liquid), book-to-market value ratio $(B T M)$, year, industry, and other factors.

If $\beta_{1}$ in Model 1 is significantly positive, a greater proportion of outstanding shares held by all mutual fund companies is presumed to increase the likelihood that a sampled firm disclosed information concverning environmental responsibility during the period 2007-2019. Hypothesis 1 is valid.

\subsubsection{Model for Hypothesis 2}

Model 2 tests Hypothesis 2.

$$
\operatorname{PDERI}_{i, t}=\beta_{0}+\beta_{1} \times \text { Top_FH }_{i, t}+\beta_{n} \times \text { Control }_{i, t}+e_{i, t} .
$$

$P D E R I_{i, t}$ takes the value of 1 if company $i$ disclosed information concerning environmental responsibility in year $t$ ( 0 otherwise). Higher values for Top_FH $H_{i, t}$ suggests that greater ownership by leading mutual fund companies implies their greater involvement in company activities and therefore greater environmental disclosure. Following Huang and 
Kung [47] and D'Amico et al. [48], Control $i_{i, t}$ governs Size, Lev, Roa, Loss, Growth, Dual, Top1, Board, Indep, Age, Div, Liquid, BTM, year, industry and other factors.

If $\beta_{1}$ is significantly positive, a greater proportion of outstanding shares held by leading mutual fund companies is presumed to increase the likelihood that a sampled firm disclosed information concerning environmental responsibility during the period 2007-2019. Hypothesis 2 holds.

\section{Empirical Results and Discussion}

\subsection{Descriptive Analysis}

In Table 2, the average value of PDERI (26.00\%) indicates that $26.00 \%$ of the sampled firms disclosed information concerning environmental responsibility in social responsibility reports during the period 2007-2019. The average value of Total_FH is 3.79\%, its median is $0.96 \%$, its minimum is $0.00 \%$, its maximum is $30.90 \%$, and its standard deviation is $6.17 \%$. These results indicate the sampled firm is held by mutual funds. The disparity in total proportion is consistent with the standard deviation. That the average exceeds the median indicates that the total proportion of shares held by funds for most sampled firms is below the average.

Table 2. Summary statistics of key variables.

\begin{tabular}{ccccccc}
\hline Variable & $\mathbf{N}$ & Mean & $\mathbf{p 5 0}$ & Min & Max & sd \\
\hline PDERI & 25,188 & 0.2600 & 0.0000 & 0.0000 & 1.0000 & 0.4390 \\
Total_FH & 25,188 & 0.0379 & 0.0096 & 0.0000 & 0.3090 & 0.0617 \\
Top_FH & 25,188 & 0.0093 & 0.0006 & 0.0000 & 0.1050 & 0.0193 \\
Size & 25,188 & 12.9900 & 12.9100 & 10.5800 & 16.4500 & 1.1450 \\
Lev & 25,188 & 0.2290 & 0.0672 & 0.0000 & 2.1430 & 0.3830 \\
Roa & 25,188 & 0.0561 & 0.0417 & -0.0827 & 0.3450 & 0.0619 \\
Loss & 25,188 & 0.0413 & 0.0000 & 0.0000 & 1.0000 & 0.1990 \\
Growth & 25,188 & 0.2330 & 0.1230 & -0.5280 & 4.3700 & 0.5870 \\
Dual & 25,188 & 0.2250 & 0.0000 & 0.0000 & 1.0000 & 0.4180 \\
Top1 & 25,188 & 0.3530 & 0.3330 & 0.0877 & 0.7500 & 0.1520 \\
Board & 25,188 & 2.2720 & 2.3030 & 1.7920 & 2.7730 & 0.1850 \\
Indep & 25,188 & 0.3720 & 0.3330 & 0.3080 & 0.5710 & 0.0529 \\
Age & 25,188 & 16.5100 & 16.3000 & 4.1480 & 31.0200 & 5.7170 \\
Div & 25,188 & 0.0087 & 0.0048 & 0.0000 & 0.0577 & 0.0114 \\
Liquid & 25,188 & 6.0120 & 4.8040 & 0.4750 & 24.2000 & 4.5490 \\
BTM & 25,188 & 0.4090 & 0.3450 & 0.0480 & 1.3930 & 0.2700 \\
\hline Note: No dummy variables are Winsorized at 1\% and $99 \%$ & & &
\end{tabular}

The mean value of Top_FH is $0.93 \%$, its median is $0.06 \%$, its minimum is $0.00 \%$, its maximum is $10.50 \%$, and the standard deviation is $1.93 \%$. These results indicate that the total proportion of shares in sampled firms held by funds differs greatly from the standard deviation. The numerical value is consistent, and the average exceeds the median, indicating that proportional ownership by the largest fund companies is below the average value.

Turning to control variables, average values are Size, RMB 4380,113,100; Lev, 22.90\%; Roa, 5.61\%; Loss, $4.13 \%$; and Growth, $23.30 \%$. With an average value of $22.50 \%$, Dual indicates the CEO and chairman of the board is the same person at slightly less than one sampled firm in four.

Average values are $35.30 \%$ for Top 1, 9.7 for Board, 37.20\% for Indep, 16.51 years for Age, 0.87\% for Div, 6.0120 for Liquid, and 0.4090 for BTM.

\subsection{Correlation Analysis}

Table 3 shows that correlations of Total_FH (0.0875) and Top_FH (0.0650) with PDERI are significant at $1 \%$. The greater the proportion of shares held by all funds and by leading funds intimates their greater likely involvement in sampled firms' activities and therefore disclosures of environmental responsibility. Hypotheses 1 and 2 are supported. 
Table 3. Pearson pairwise correlation coefficients for variables.

\begin{tabular}{|c|c|c|c|c|c|c|c|c|}
\hline & PDERI & PDERI & Top_FH & Size & Lev & Roa & Loss & Growth \\
\hline PDERI & 1.0000 & & & & & & & \\
\hline Total_FH & $0.0875^{* * *}$ & 1.0000 & & & & & & \\
\hline Top_FH & $0.0650^{* * *}$ & $0.8028^{* * *}$ & 1.0000 & & & & & \\
\hline Size & $0.4348^{* * *}$ & $0.2976^{* * *}$ & $0.2086^{* * *}$ & 1.0000 & & & & \\
\hline Lev & $0.1707^{* * *}$ & $-0.0390^{* * *}$ & $-0.0275^{* * *}$ & $0.2236^{* * *}$ & 1.0000 & & & \\
\hline Roa & -0.0089 & $0.2946^{* * *}$ & $0.2278^{* * *}$ & $0.0838^{* * *}$ & $-0.1982 * * *$ & 1.0000 & & \\
\hline Loss & $-0.0161^{* *}$ & $-0.0709^{* * *}$ & $-0.0607^{* * *}$ & $-0.0321^{* * *}$ & $0.0514^{* * *}$ & $-0.3357^{* * *}$ & 1.0000 & \\
\hline Growth & $-0.0471^{* * *}$ & $0.0484^{* * *}$ & $0.0330^{* * *}$ & -0.0048 & $0.0328^{* * *}$ & $0.3712 * * *$ & $-0.0926^{* * *}$ & 1.0000 \\
\hline Dual & $-0.0883^{* * *}$ & -0.0044 & -0.0099 & $-0.1136^{* * *}$ & $-0.1048^{* * *}$ & $0.0547^{* * *}$ & 0.0046 & 0.0102 * \\
\hline Top1 & $0.0738^{* * *}$ & $-0.0632^{* * *}$ & $-0.0386^{* * *}$ & $0.0682 * * *$ & $0.0722 * * *$ & $0.0947^{* * *}$ & $-0.0335^{* * *}$ & $0.0204^{* * *}$ \\
\hline Board & $0.1576^{* * *}$ & $0.0720 * * *$ & $0.0709 * * *$ & $0.2148^{* * *}$ & $0.1615^{* * *}$ & $-0.0287^{* * *}$ & $-0.0231^{* * *}$ & $-0.0282^{* * *}$ \\
\hline Indep & $0.0336^{* * *}$ & $-0.0197^{* * *}$ & $-0.0212^{* * *}$ & $0.0524^{* * *}$ & 0.0021 & $-0.0112 *$ & $0.0123 *$ & 0.0075 \\
\hline Age & $0.1241^{* * *}$ & $-0.1173^{* * *}$ & $-0.1119^{* * *}$ & $0.2396^{* * *}$ & $0.1653^{* * *}$ & $-0.1094^{* * *}$ & $0.0172^{* * *}$ & -0.0096 \\
\hline Div & $0.2191 * * *$ & $0.0278^{* * *}$ & $0.0240^{* * *}$ & $0.2323^{* * *}$ & $0.0795^{* * *}$ & $0.2000^{* * *}$ & $-0.1328^{* * *}$ & $-0.0457^{* * *}$ \\
\hline Liquid & $-0.2212^{* * *}$ & $-0.1793^{* * *}$ & $-0.1374^{* * *}$ & $-0.4203^{* * *}$ & $-0.1392 * * *$ & $-0.0279 * * *$ & $0.0433^{* * *}$ & -0.0029 \\
\hline \multirow[t]{2}{*}{ BTM } & $0.2190^{* * *}$ & $-0.2151^{* * *}$ & $-0.1710^{* * *}$ & $0.0854^{* * *}$ & $0.2343^{* * *}$ & $-0.2537^{* * *}$ & $0.0402^{* * *}$ & $-0.1013^{* * *}$ \\
\hline & Dual & Top1 & Board & Indep & Age & Div & Liquid & BTM \\
\hline Dual & 1.0000 & & & & & & & \\
\hline Top1 & $-0.0594^{* * *}$ & 1.0000 & & & & & & \\
\hline Board & $-0.1794^{* * *}$ & 0.0084 & 1.0000 & & & & & \\
\hline Indep & $0.1016^{* * *}$ & $0.0442 * * *$ & $-0.4660^{* * *}$ & 1.0000 & & & & \\
\hline Age & $-0.0728^{* * *}$ & $-0.1328^{* * *}$ & 0.0068 & 0.0043 & 1.0000 & & & \\
\hline Div & $-0.0436^{* * *}$ & $0.1666^{* * *}$ & $0.1657^{* * *}$ & $-0.0238^{* * *}$ & $0.0534^{* * *}$ & 1.0000 & & \\
\hline Liquid & $0.0977^{* * *}$ & $-0.0964^{* * *}$ & $-0.1190^{* * *}$ & -0.0030 & $-0.1755^{* * *}$ & $-0.2150^{* * *}$ & 1.0000 & \\
\hline BTM & $-0.0991^{* * *}$ & $0.0581^{* * *}$ & $0.1435^{* * *}$ & $0.0189 * * *$ & $0.1824^{* * *}$ & $0.3699 * * *$ & $-0.2491^{* * *}$ & 1.0000 \\
\hline
\end{tabular}

\subsection{Regression Analysis}

Table 4 shows regression results for Size, Lev, Roa, Loss, Growth, Dual, Top1, Board, Indep, Age, Div, Liquid, BTM, year, industry and other factors. Coefficients of Total_FH (0.7726) and Top_FH (2.2155) with PDERI are significant at 5\%. A greater proportion of shares held by all mutual funds and by leading funds intimates their greater likely involvement in sampled firms' activities and therefore disclosures of environmental responsibility. Hypotheses 1 and 2 are confirmed.

Table 4. Regression analysis.

\begin{tabular}{ccc}
\hline & $(1)$ & $(2)$ \\
& PDERI & PDERI \\
\hline Total_FH & $0.7726^{* *}$ & \\
Top_FH & $(2.3323)$ & $2.2155^{* *}$ \\
& & $(2.2848)$ \\
Size & & $1.0471^{* * *}$ \\
& $1.0420^{* * *}$ & $(43.4433)$ \\
Lev & $(42.2848)$ & $0.2327^{* * *}$ \\
& $0.2312^{* * *}$ & $(4.5355)$ \\
Roa & $(4.5033)$ & -0.4409 \\
& -0.5042 & $(-1.1514)$ \\
Loss & $(-1.2997)$ & -0.0292 \\
& -0.0322 & $(-0.3198)$ \\
Growth & $(-0.3528)$ & $-0.1465 * * *$ \\
& $-0.1455^{* * *}$ & $(-3.9084)$ \\
\hline
\end{tabular}


Table 4. Cont.

\begin{tabular}{ccc}
\hline Dual & $-0.1600^{* * * *}$ & $-0.1600^{* * *}$ \\
Top1 & $(-3.5865)$ & $(-3.5865)$ \\
& $0.3033^{* * *}$ & $0.2878^{* *}$ \\
Board & $(2.4332)$ & $(2.3257)$ \\
& $0.7329^{* * *}$ & $0.7309^{* * *}$ \\
Indep & $(6.2422)$ & $(6.2259)$ \\
& $1.4279^{* * *}$ & $1.4200^{* * *}$ \\
Age & $(3.8801)$ & $(3.8589)$ \\
& $0.0115^{* * *}$ & $0.0112^{* * *}$ \\
Div & $(3.1381)$ & $(3.0671)$ \\
& $10.0869^{* * *}$ & $10.0453^{* * *}$ \\
Liquid & $(5.8582)$ & $(5.8372)$ \\
& $0.0135^{* * *}$ & $0.0131^{* *}$ \\
BTM & $(2.5886)$ & $(2.5171)$ \\
& $1.2406^{* * *}$ & $1.2338^{* * *}$ \\
Year & $(14.6102)$ & $(14.5938)$ \\
Industry & Yes & Yes \\
cut1_cons & Yes & Yes \\
& $-18.8264^{* * *}$ & $-18.8585^{* * *}$ \\
N & $(-35.0928)$ & $(-35.2374)$ \\
pseudo $R^{2}$ & 25,188 & 25,188 \\
chi2 & 0.232 & 0.232 \\
\hline
\end{tabular}

Z statistics in parentheses. ${ }^{*} p<0.10,{ }^{* *} p<0.05,{ }^{* * *} p<0.01$.

\subsection{Heterogeneity Test}

\subsubsection{Analyst Coverage}

Analyst coverage may affect fund managers' involvement with listed companies. Therefore, we divided our sample into firms that were and were not covered by securities analysts during the period 2007-2019. Analyst takes the value of 1 if the sampled firm was followed by an analyst during the year ( 0 otherwise). We then regressed the two groups based on data in the main effects models 1 and 2. Results appear in Table 5.

Table 5. Security analyst following.

\begin{tabular}{|c|c|c|c|c|}
\hline & \multicolumn{2}{|c|}{ Analyst $=0$} & \multicolumn{2}{|c|}{ Analyst $=1$} \\
\hline & $\begin{array}{c}(1) \\
\text { PDERI }\end{array}$ & $\begin{array}{c}(2) \\
P D E R I\end{array}$ & $\begin{array}{c}\text { (3) } \\
\text { PDERI }\end{array}$ & $\begin{array}{c}(4) \\
P D E R I\end{array}$ \\
\hline Total_FH & $\begin{array}{c}6.6271^{* * *} \\
(2.9575)\end{array}$ & & $\begin{array}{c}0.2562 \\
(0.7351)\end{array}$ & \\
\hline Top_FH & & $\begin{array}{c}7.2811 \\
(1.2463)\end{array}$ & & $\begin{array}{c}1.0495 \\
(1.0386)\end{array}$ \\
\hline Size & $\begin{array}{l}0.9581^{* * *} \\
(12.3052)\end{array}$ & $\begin{array}{l}0.9933^{* * *} \\
(12.9165)\end{array}$ & $\begin{array}{l}1.0421^{* * *} \\
(38.5222)\end{array}$ & $\begin{array}{l}1.0419^{* * *} \\
(39.1857)\end{array}$ \\
\hline Lev & $\begin{array}{l}0.2050 * \\
(1.8531)\end{array}$ & $\begin{array}{l}0.2068 \text { * } \\
(1.8688)\end{array}$ & $\begin{array}{c}0.2359 * * * \\
(3.9896)\end{array}$ & $\begin{array}{c}0.2366^{* * *} \\
(4.0014)\end{array}$ \\
\hline Roa & $\begin{array}{c}-0.0671 \\
(-0.0599)\end{array}$ & $\begin{array}{l}-0.1002 \\
(-0.0897)\end{array}$ & $\begin{array}{l}-0.5459 \\
(-1.2930)\end{array}$ & $\begin{array}{l}-0.5433 \\
(-1.3011)\end{array}$ \\
\hline Loss & $\begin{array}{c}0.1617 \\
(0.8876)\end{array}$ & $\begin{array}{c}0.1621 \\
(0.8907)\end{array}$ & $\begin{array}{l}-0.0779 \\
(-0.7208)\end{array}$ & $\begin{array}{l}-0.0773 \\
(-0.7155)\end{array}$ \\
\hline Growth & $\begin{array}{l}-0.0333 \\
(-0.4118)\end{array}$ & $\begin{array}{l}-0.0334 \\
(-0.4139)\end{array}$ & $\begin{array}{c}-0.1823^{* * *} \\
(-4.2349)\end{array}$ & $\begin{array}{c}-0.1825^{* * *} \\
(-4.2411)\end{array}$ \\
\hline Dual & $\begin{array}{c}-0.4665^{* * *} \\
(-3.7071)\end{array}$ & $\begin{array}{c}-0.4729 * * * \\
(-3.7605)\end{array}$ & $\begin{array}{l}-0.1207^{* * *} \\
(-2.4885)\end{array}$ & $\begin{array}{l}-0.1212 * * \\
(-2.4984)\end{array}$ \\
\hline Top1 & $\begin{array}{l}0.7443^{* *} \\
(2.4152)\end{array}$ & $\begin{array}{l}0.7217 * * \\
(2.3447)\end{array}$ & $\begin{array}{c}0.1700 \\
(1.2273)\end{array}$ & $\begin{array}{c}0.1700 \\
(1.2392)\end{array}$ \\
\hline
\end{tabular}


Table 5. Cont.

\begin{tabular}{ccccc}
\hline Board & $0.7358^{* *}$ & $0.7288^{* * *}$ & $0.6886^{* * *}$ & $0.6882^{* * *}$ \\
& $(2.2848)$ & $(2.2677)$ & $(5.3676)$ & $(5.3650)$ \\
Indep & -0.5328 & -0.5718 & $1.7142^{* * * *}$ & $1.7131^{* * *}$ \\
& $(-0.5225)$ & $(-0.5616)$ & $(4.2710)$ & $(4.2686)$ \\
Age & 0.0081 & 0.0080 & $0.0151^{* * *}$ & $0.0150^{* * *}$ \\
& $(0.8470)$ & $(0.8365)$ & $(3.7411)$ & $(3.7297)$ \\
Div & $10.5895^{* *}$ & $10.7282^{* *}$ & $9.3369^{* * *}$ & $9.3477^{* * *}$ \\
& $(2.0449)$ & $(2.0748)$ & $(4.9975)$ & $(5.0078)$ \\
Liquid & 0.0040 & 0.0044 & $0.0124^{* *}$ & $0.0124^{* *}$ \\
& $(0.3520)$ & $(0.3842)$ & $(2.0607)$ & $(2.0731)$ \\
BTM & $0.8337^{* * *}$ & $0.8272^{* * *}$ & $1.3345^{* * *}$ & $1.3354^{* * *}$ \\
& $(4.4350)$ & $(4.4040)$ & $(13.5799)$ & $(13.6746)$ \\
Year & Yes & Yes & Yes & Yes \\
Industry & Yes & Yes & Yes & Yes \\
cut1_cons & $-16.0138^{* * *}$ & $-16.4235^{* * *}$ & $-19.0553 * * *$ & $-19.0465 * * *$ \\
& $(-11.1623)$ & $(-11.5051)$ & $(-31.8035)$ & $(-31.8220)$ \\
\hline$N$ & 5675 & 5675 & 19,513 & 19,513 \\
pseudo $R^{2}$ & 0.171 & 0.170 & 0.237 & 0.237 \\
chi2 & 742.8164 & 736.0970 & $5.5 \times 10^{3}$ & $5.5 \times 10^{3}$ \\
\hline z statistics in parentheses. ${ }^{*} p<0.10, * * p<0.05, * * *$ & $p<0.01$. & &
\end{tabular}

Among the sampled firms not covered by analysts, coefficients of Total_FH (6.6271) and Top_FH (7.2811) with PDERI are, respectively, significant at $1 \%$ and not statistically significant. Among the sampled firms covered by analysts, coefficients of Total_FH (0.2562) and Top_FH (1.0495) are not statistically significant. We interpret these results to mean that mutual funds can be more activist investors when sampled firms are not followed by analysts, intimating greater disclosure of information concerning environmental responsibility.

\subsubsection{Ownership}

China has established capital markets to assure financing for state-owned enterprises (SOEs), and SOEs constitute an important proportion of equities traded on China's capital markets. To consider the effects of ownership on our hypotheses, we divided our sample into SOEs and non-SOEs and assigned the value of 1 if a sampled firm is state-owned (0 otherwise). We then re-regressed based on data in the main effects model. Results appear in Table 6.

Table 6. Correlations for SOEs and non-SOEs.

\begin{tabular}{|c|c|c|c|c|}
\hline & \multicolumn{2}{|c|}{$S O E=0$} & \multicolumn{2}{|c|}{$S O E=1$} \\
\hline & $\begin{array}{c}(1) \\
\text { PDERI }\end{array}$ & $\begin{array}{c}(2) \\
P D E R I\end{array}$ & $\begin{array}{c}\text { (3) } \\
\text { PDERI }\end{array}$ & $\begin{array}{c}(4) \\
P D E R I\end{array}$ \\
\hline Total_FH & $\begin{array}{c}-0.3985 \\
(-0.8349)\end{array}$ & & $\begin{array}{c}1.5973^{* * *} \\
(3.2409)\end{array}$ & \\
\hline Top_FH & & $\begin{array}{l}-0.5883 \\
(-0.4248)\end{array}$ & & $\begin{array}{c}4.3899 * * * \\
(3.0280)\end{array}$ \\
\hline Size & $\begin{array}{l}1.0389 * * * \\
(28.6756)\end{array}$ & $\begin{array}{l}1.0326^{* * *} \\
(29.2763)\end{array}$ & $\begin{array}{l}1.0342^{* * *} \\
(27.5594)\end{array}$ & $\begin{array}{l}1.0456^{* * *} \\
(28.3800)\end{array}$ \\
\hline Lev & $\begin{array}{c}0.3007^{* * *} \\
(3.1543)\end{array}$ & $\begin{array}{c}0.3005^{* * *} \\
(3.1512)\end{array}$ & $\begin{array}{l}0.1266^{* *} \\
(1.9847)\end{array}$ & $\begin{array}{l}0.1298 * * \\
(2.0356)\end{array}$ \\
\hline Roa & $\begin{array}{l}1.1299 * * \\
(2.2775)\end{array}$ & $\begin{array}{l}1.0676^{* *} \\
(2.1818)\end{array}$ & $\begin{array}{l}-1.6344^{* *} \\
(-2.4550)\end{array}$ & $\begin{array}{l}-1.5049 \text { ** } \\
(-2.2808)\end{array}$ \\
\hline Loss & $\begin{array}{c}0.1060 \\
(0.7764)\end{array}$ & $\begin{array}{c}0.1029 \\
(0.7541)\end{array}$ & $\begin{array}{l}-0.0340 \\
(-0.2595)\end{array}$ & $\begin{array}{l}-0.0279 \\
(-0.2128)\end{array}$ \\
\hline Growth & $\begin{array}{c}-0.1400^{* * *} \\
(-2.7376)\end{array}$ & $\begin{array}{c}-0.1392^{* * *} \\
(-2.7195)\end{array}$ & $\begin{array}{l}-0.1027^{*} \\
(-1.8238)\end{array}$ & $\begin{array}{l}-0.1056^{*} \\
(-1.8780)\end{array}$ \\
\hline Dual & -0.0626 & -0.0630 & -0.0269 & -0.0241 \\
\hline
\end{tabular}


Table 6. Cont.

\begin{tabular}{|c|c|c|c|c|}
\hline & $(-1.1174)$ & $(-1.1247)$ & $(-0.3135)$ & $(-0.2812)$ \\
\hline \multirow[t]{2}{*}{ Top1 } & $-0.3761^{* *}$ & $-0.3605^{*}$ & 0.2581 & 0.2256 \\
\hline & $(-1.9700)$ & $(-1.8993)$ & $(1.3617)$ & (1.1986) \\
\hline \multirow{2}{*}{ Board } & $0.7706^{* * *}$ & $0.7721^{* * *}$ & $0.4532^{* * *}$ & $0.4521^{* * *}$ \\
\hline & $(4.0734)$ & $(4.0806)$ & $(2.8097)$ & $(2.8017)$ \\
\hline \multirow[t]{2}{*}{ Indep } & $2.6050^{* * *}$ & $2.6066^{* * *}$ & 0.0952 & 0.0574 \\
\hline & $(4.5160)$ & $(4.5188)$ & $(0.1852)$ & $(0.1117)$ \\
\hline \multirow[t]{2}{*}{ Age } & $0.0127^{* *}$ & 0.0130 ** & $-0.0206^{* * *}$ & $-0.0209^{* * *}$ \\
\hline & $(2.4708)$ & $(2.5323)$ & $(-3.3947)$ & $(-3.4395)$ \\
\hline \multirow[t]{2}{*}{ Div } & $17.3645^{* * *}$ & $17.4452 * * *$ & $6.2034 * *$ & $6.2107 * *$ \\
\hline & $(7.2564)$ & $(7.2971)$ & $(2.3529)$ & $(2.3543)$ \\
\hline \multirow[t]{2}{*}{ Liquid } & $0.0195^{* * *}$ & $0.0200^{* * *}$ & 0.0028 & 0.0019 \\
\hline & $(2.7753)$ & $(2.8596)$ & $(0.3318)$ & $(0.2238)$ \\
\hline \multirow[t]{2}{*}{ BTM } & $1.1484^{* * *}$ & $1.1601^{* * *}$ & $1.1052^{* * *}$ & $1.0949^{* * *}$ \\
\hline & $(8.8516)$ & $(9.0051)$ & $(9.0530)$ & $(8.9904)$ \\
\hline Year & Yes & Yes & Yes & Yes \\
\hline \multirow{3}{*}{$\begin{array}{l}\text { Industry } \\
\text { cut1_cons }\end{array}$} & Yes & Yes & Yes & Yes \\
\hline & $-18.3015^{* * *}$ & $-18.2519^{* * *}$ & $-17.3640^{* * *}$ & $-17.4520^{* * *}$ \\
\hline & $(-22.1490)$ & $(-22.1308)$ & $(-22.4889)$ & $(-22.6563)$ \\
\hline$N$ & 14,081 & 14,081 & 11,107 & 11,107 \\
\hline \multirow{2}{*}{$\begin{array}{c}\text { pseudo } R^{2} \\
\text { chi2 }\end{array}$} & 0.205 & 0.205 & 0.252 & 0.252 \\
\hline & $2.7 \times 10^{3}$ & $2.7 \times 10^{3}$ & $3.4 \times 10^{3}$ & $3.4 \times 10^{3}$ \\
\hline
\end{tabular}

Among non-SOEs owned by mutual funds, the coefficients of Total_FH $(-0.3985)$ and Top_FH (-0.5883) are not statistically significant. Among SOEs, coefficients of Total_FH (1.5973) and Top_FH (4.3899) with PDERI are significant at 1\%.

We interpret these results to mean that mutual funds can be more activist investors in SOEs, intimating a greater likelihood of their disclosing environmental responsibility. The more shares held by the largest fund companies, the stronger is the likelihood.

\subsubsection{New Environmental Protection Law}

On 24 April 2014, the eighth meeting of the Standing Committee of the 12th National People's Congress amended China's Environmental Protection Law. After its implementation on 1 January 2015, listed companies faced stricter environmental supervision and enforcement. Therefore, we examined the periods before and after implementation to re-examine our hypotheses. For years 2015 and after (pre-2015) the variable New bears a value of $1(0)$. We then regressed this dummy based on data in the main effects model. Results appear in Table 7.

Table 7. Effects of China's New Environmental Protection Law.

\begin{tabular}{|c|c|c|c|c|}
\hline & \multicolumn{2}{|c|}{$N e w=0$} & \multicolumn{2}{|c|}{$N e w=1$} \\
\hline & $\begin{array}{c}(1) \\
P D E R I\end{array}$ & $\begin{array}{c}(2) \\
P D E R I\end{array}$ & $\begin{array}{c}(3) \\
P D E R I\end{array}$ & $\begin{array}{c}(4) \\
P D E R I\end{array}$ \\
\hline Total_FH & $\begin{array}{l}0.5991^{* *} \\
(2.5431)\end{array}$ & & $\begin{array}{c}-0.4807 \\
(-1.2750)\end{array}$ & \\
\hline Top_FH & & $\begin{array}{l}2.9477^{* *} \\
(2.5610)\end{array}$ & & $\begin{array}{c}-2.1111 \\
(-0.9726)\end{array}$ \\
\hline Size & $\begin{array}{l}1.0188^{* * *} \\
(28.8525)\end{array}$ & $\begin{array}{l}1.0285^{* * *} \\
(29.5706)\end{array}$ & $\begin{array}{l}1.1332 * * * \\
(31.2243)\end{array}$ & $\begin{array}{l}1.1262^{* * *} \\
(32.0159)\end{array}$ \\
\hline Lev & $\begin{array}{c}0.3306^{* * *} \\
(4.4094)\end{array}$ & $\begin{array}{c}0.3343^{* * *} \\
(4.4614)\end{array}$ & $\begin{array}{c}0.1143 \\
(1.5421)\end{array}$ & $\begin{array}{c}0.1138 \\
(1.5342)\end{array}$ \\
\hline Roa & 0.5084 & 0.6412 & $-1.8122^{* * *}$ & $-1.8851^{* * *}$ \\
\hline
\end{tabular}


Table 7. Cont.

\begin{tabular}{|c|c|c|c|c|}
\hline & $(0.9506)$ & $(1.2154)$ & $(-3.1181)$ & $(-3.2783)$ \\
\hline \multirow[t]{2}{*}{ Loss } & 0.0327 & 0.0371 & -0.1405 & -0.1445 \\
\hline & $(0.2241)$ & $(0.2542)$ & $(-1.1714)$ & $(-1.2052)$ \\
\hline \multirow[t]{2}{*}{ Growth } & -0.1044 * & -0.1063 * & $-0.1686^{* * *}$ & $-0.1675^{* * *}$ \\
\hline & $(-1.9078)$ & $(-1.9467)$ & $(-3.2273)$ & $(-3.2037)$ \\
\hline \multirow[t]{2}{*}{ Dual } & $-0.1521 * *$ & $-0.1507^{* *}$ & $-0.1545^{* *}$ & $-0.1547^{* *}$ \\
\hline & $(-2.2862)$ & $(-2.2666)$ & $(-2.5346)$ & $(-2.5384)$ \\
\hline \multirow[t]{2}{*}{ Top1 } & 0.1127 & 0.0786 & $0.4172 * *$ & $0.4335^{* *}$ \\
\hline & $(0.6458)$ & $(0.4540)$ & $(2.2842)$ & $(2.3905)$ \\
\hline \multirow[t]{2}{*}{ Board } & $0.5796^{* * *}$ & $0.5798^{* * *}$ & $0.9054^{* * *}$ & $0.9088^{* * *}$ \\
\hline & $(3.5515)$ & $(3.5516)$ & $(5.2037)$ & $(5.2239)$ \\
\hline \multirow[t]{2}{*}{ Indep } & 0.9757 * & 0.9684 * & $1.8873^{* * *}$ & $1.9008^{* * *}$ \\
\hline & (1.9005) & (1.8865) & $(3.4815)$ & $(3.5074)$ \\
\hline \multirow[t]{2}{*}{ Age } & 0.0037 & 0.0032 & $0.0187^{* * *}$ & $0.0190^{* * *}$ \\
\hline & $(0.6925)$ & $(0.5950)$ & $(3.6913)$ & $(3.7532)$ \\
\hline \multirow[t]{2}{*}{ Div } & $13.6890 * * *$ & $13.5731^{* * *}$ & $6.3698^{* * *}$ & $6.4251^{* * *}$ \\
\hline & $(5.3855)$ & $(5.3445)$ & $(2.6684)$ & $(2.6932)$ \\
\hline \multirow[t]{2}{*}{ Liquid } & $0.0197^{* *}$ & $0.0182 * *$ & 0.0115 * & $0.0117^{*}$ \\
\hline & $(2.4384)$ & $(2.2657)$ & $(1.6556)$ & $(1.6926)$ \\
\hline \multirow[t]{2}{*}{ BTM } & $1.4041^{* * *}$ & $1.3844^{* * *}$ & $1.0389 * * *$ & $1.0455^{* * *}$ \\
\hline & $(10.2194)$ & $(10.1285)$ & $(9.2688)$ & $(9.3650)$ \\
\hline Year & Yes & Yes & Yes & Yes \\
\hline \multirow{3}{*}{$\begin{array}{l}\text { Industry } \\
\text { cut1_cons }\end{array}$} & Yes & Yes & Yes & Yes \\
\hline & $-17.6201^{* * *}$ & $-17.6841^{* * *}$ & $-20.6911^{* * *}$ & $-20.6258^{* * *}$ \\
\hline & $(-24.0359)$ & $(-24.1452)$ & $(-25.4993)$ & $(-25.5429)$ \\
\hline$N$ & 13,932 & 13,932 & 11,256 & 11,256 \\
\hline pseudo $R^{2}$ & 0.235 & 0.235 & 0.235 & 0.235 \\
\hline chi2 & $3.3 \times 10^{3}$ & $3.3 \times 10^{3}$ & $3.2 \times 10^{3}$ & $3.2 \times 10^{3}$ \\
\hline
\end{tabular}

Among the pre-2015 sample, coefficients of Total_FH (0.5591) and Top_FH (2.9477) with PDERI are significant at $5 \%$. Among the post-2015 group, coefficients of Total_FH $(-0.4807)$ and Top_FH (-2.111) with PDERI are not statistically significant. Comparing these results implies that, before 2015, mutual funds exercised the role later filled by changing the law. We interpret these results as again suggesting that mutual fund activism correlates with firms disclosing environmental responsibility.

\subsection{Robustness Test}

\subsubsection{Endogeneity Test}

Reverse Causality

Our results potentially suffer from reverse causality. That is, funds did not prompt sampled companies to disclose environmental responsibility; rather, firms disclosed it to curry favor with mutual funds. To address this problem, we regressed values for Total_FH and Top_FH with one-period lags $(t-1)$. In Table 8, their correlations with PDERI (1.5611 and 4.6146 , respectively) are significant at $1 \%$. The greater the proportion of outstanding stock held by institutional investors, such as mutual funds, the more environmental information they disclosed during the period 2007-2019. Again, these results imply the activist role of mutual funds in firms' tendency to disclose environmental information. Hypotheses 1 and 2 remain valid.

Next, we regressed the independent and control variables by one period $(t-1)$. Results in Table 9 show that the coefficients of Top_FH (0.9269) and PDERI (3.1145) are significant at $1 \%$. The greater the proportion of outstanding shares held by investors, and leading funds, the more likely it was that sampled companies disclosed environmental responsibility during the period 2007-2019. Again, the implication is that mutual fund activism encouraged environmental disclosures. Hypotheses 1 and 2 remain valid. 
Table 8. Variables lagged one period.

\begin{tabular}{|c|c|c|}
\hline & (1) & (2) \\
\hline & PDERI & PDERI \\
\hline Total_FH & $\begin{array}{c}1.5611^{* * *} \\
(4.9879)\end{array}$ & \\
\hline Top_FH & & $\begin{array}{c}4.6146^{* * *} \\
(4.9668)\end{array}$ \\
\hline Size & $\begin{array}{l}1.0419^{* * *} \\
(39.0967)\end{array}$ & $\begin{array}{l}1.0519^{* * *} \\
(40.1689)\end{array}$ \\
\hline Lev & $\begin{array}{c}0.1970 * * * \\
(3.5118)\end{array}$ & $\begin{array}{c}0.2007^{* * *} \\
(3.5797)\end{array}$ \\
\hline Roa & $\begin{array}{c}-1.3229 * * * \\
(-3.0075)\end{array}$ & $\begin{array}{c}-1.1857^{* * * *} \\
(-2.7309)\end{array}$ \\
\hline Loss & $\begin{array}{l}-0.0751 \\
(-0.7861)\end{array}$ & $\begin{array}{l}-0.0666 \\
(-0.6980)\end{array}$ \\
\hline Growth & $\begin{array}{c}-0.1863 * * * \\
(-4.1844)\end{array}$ & $\begin{array}{c}-0.1876^{* * * *} \\
(-4.2229)\end{array}$ \\
\hline Dual & $\begin{array}{c}-0.1624^{* * *} \\
(-3.3723)\end{array}$ & $\begin{array}{c}-0.1629^{* * * *} \\
(-3.3826)\end{array}$ \\
\hline Top1 & $\begin{array}{l}0.2280 * \\
(1.6955)\end{array}$ & $\begin{array}{c}0.1969 \\
(1.4739)\end{array}$ \\
\hline Board & $\begin{array}{c}0.7063^{* * *} \\
(5.6445)\end{array}$ & $\begin{array}{c}0.7027^{* * *} \\
(5.6141)\end{array}$ \\
\hline Indep & $\begin{array}{c}1.6052^{* * *} \\
(4.1067)\end{array}$ & $\begin{array}{c}1.5913^{* * * *} \\
(4.0704)\end{array}$ \\
\hline Age & $\begin{array}{c}0.0167^{* * * *} \\
(4.2280)\end{array}$ & $\begin{array}{c}0.0162^{* * * *} \\
(4.1043)\end{array}$ \\
\hline Div & $\begin{array}{c}10.9605^{* * *} \\
(5.9773)\end{array}$ & $\begin{array}{c}10.9025^{* * *} \\
(5.9472)\end{array}$ \\
\hline Liquid & $\begin{array}{c}0.0070 \\
(1.1580)\end{array}$ & $\begin{array}{c}0.0070 \\
(1.1672)\end{array}$ \\
\hline BTM & $\begin{array}{l}1.2057^{* * *} \\
(13.2949)\end{array}$ & $\begin{array}{l}1.1988^{* * *} \\
(13.2339)\end{array}$ \\
\hline Year & Yes & Yes \\
\hline Industry & Yes & Yes \\
\hline cut1_cons & $\begin{array}{c}-18.9268^{* * *} \\
(-33.0391)\end{array}$ & $\begin{array}{c}-18.9658^{* * *} \\
(-33.1299)\end{array}$ \\
\hline$N$ & 20,167 & 20,167 \\
\hline pseudo $R^{2}$ & 0.232 & 0.232 \\
\hline chi2 & $5.7 \times 10^{3}$ & $5.7 \times 10^{3}$ \\
\hline
\end{tabular}

z statistics in parentheses. ${ }^{*} p<0.10,{ }^{* *} p<0.05,{ }^{* * *} p<0.01$.

Table 9. One-period lagged values of independent and control variables.

\begin{tabular}{ccc}
\hline & $(1)$ & $(2)$ \\
\hline Total_FH & PDERI & PDERI \\
& $0.9269^{* * *}$ & \\
Top_FH & $(2.8417)$ & $3.1145^{* * *}$ \\
Size & & $(3.2505)$ \\
& & $1.0836^{* * *}$ \\
Lev & $1.0808^{* * *}$ & $(41.0692)$ \\
& $(40.2290)$ & $0.2310^{* * *}$ \\
Roa & $0.2288^{* * *}$ & $(4.1183)$ \\
& $(4.0784)$ & 0.4802 \\
Loss & 0.4341 & $(1.2190)$ \\
\end{tabular}


Table 9. Cont.

\begin{tabular}{|c|c|c|}
\hline & $(0.4341)$ & $(0.4722)$ \\
\hline \multirow[t]{2}{*}{ Growth } & $-0.1082 * * *$ & $-0.1096^{* * *}$ \\
\hline & $(-2.8593)$ & $(-2.8980)$ \\
\hline \multirow[t]{2}{*}{ Dual } & $-0.1467^{* * *}$ & $-0.1466^{* * *}$ \\
\hline & $(-3.0503)$ & $(-3.0475)$ \\
\hline \multirow[t]{2}{*}{ Top1 } & 0.3376 ** & $0.3258 * *$ \\
\hline & $(2.5450)$ & $(2.4729)$ \\
\hline \multirow[t]{2}{*}{ Board } & $0.6729 * * *$ & $0.6722^{* * *}$ \\
\hline & $(5.4098)$ & (5.4033) \\
\hline \multirow[t]{2}{*}{ Indep } & $1.3778^{* * *}$ & $1.3732^{* * *}$ \\
\hline & $(3.4924)$ & $(3.4807)$ \\
\hline \multirow[t]{2}{*}{ Age } & $0.0132 * * *$ & $0.0129^{* * *}$ \\
\hline & $(3.3272)$ & $(3.2581)$ \\
\hline \multirow[t]{2}{*}{ Div } & $11.3255^{* * *}$ & $11.3122^{* * *}$ \\
\hline & $(5.9383)$ & $(5.9332)$ \\
\hline \multirow[t]{2}{*}{ Liquid } & $0.0200 * * *$ & $0.0196^{* * *}$ \\
\hline & $(3.5751)$ & $(3.5116)$ \\
\hline \multirow[t]{2}{*}{ BTM } & $1.1449^{* * *}$ & $1.1414^{* * *}$ \\
\hline & (11.5682) & (11.5869) \\
\hline Year & Yes & Yes \\
\hline \multirow{3}{*}{$\begin{array}{l}\text { Industry } \\
\text { cut1_cons }\end{array}$} & Yes & Yes \\
\hline & $-19.7978^{* * *}$ & $-19.7971^{* * *}$ \\
\hline & $(-33.8051)$ & $(-33.8258)$ \\
\hline$N$ & 20,167 & 20,167 \\
\hline pseudo $R^{2}$ & 0.236 & 0.236 \\
\hline chi2 & $5.8 \times 10^{3}$ & $5.8 \times 10^{3}$ \\
\hline
\end{tabular}

Z statistics in parentheses. ${ }^{*} p<0.10,{ }^{* *} p<0.05,{ }^{* * *} p<0.01$.

\section{Propensity Score Matching}

Companies might disclose their environmental responsibility for reasons other than ownership by mutual funds. Therefore, we adopted propensity score matching (PSM) to identify sampled companies with similar characteristics. We used the propensity score for one-to-one matching and re-ran the main effects model based on the matched samples. The procedure involved four steps. We first constructed a PSM sample and divided samples into two groups according to median values of Total_FH and Top_FH. We set high Total_FH and Top_FH companies as the experimental group (dummy $=1)$ and low Total_FH and Top_FH companies as the control group (dummy $=0$ ). Second, we calculated the propensity matching score. Using data for the control variable, we used a logit model to calculate the probability that the sampled company will become a high Total_FH and high Top_FH. Third, we matched the samples using one-to-one nearest-neighbor matching and used the matches to regress the main effects model.

Results for $t$-tests after grouping and matching appear in Table 10. Except for the dependent variable, the fact that there were no significant differences among control variables indicates that the sampled firms disclosed environmental information. Hypotheses 1 and 2 remain valid.

Table 10. $t$-test results for intra-group differences.

\begin{tabular}{cccccc}
\hline \multirow{2}{*}{ Panel A } & \multicolumn{2}{c}{ Dummy_Total_FH=1 } & \multicolumn{2}{c}{ Dummy_Total_FH $=0$} & \multirow{2}{*}{ MeanDiff } \\
\cline { 2 - 4 } & G2(1) & Mean2 & G1(0) & Mean1 & \\
\hline PDERI & 5793 & 0.2270 & 5793 & 0.2130 & 0.0140 * \\
Size & 5793 & 12.7700 & 5793 & 12.8000 & -0.0300 \\
Lev & 5793 & 0.2210 & 5793 & 0.2230 & -0.0020 \\
Roa & 5793 & 0.0490 & 5793 & 0.0510 & -0.0020 \\
\hline
\end{tabular}


Table 10. Cont.

\begin{tabular}{cccccc}
\hline Loss & 5793 & 0.0490 & 5793 & 0.0480 & 0.0010 \\
Growth & 5793 & 0.2250 & 5793 & 0.2300 & -0.0050 \\
Dual & 5793 & 0.2320 & 5793 & 0.2310 & 0.0010 \\
Top1 & 5793 & 0.3500 & 5793 & 0.3530 & -0.0030 \\
Board & 5793 & 2.2620 & 5793 & 2.2650 & -0.0030 \\
Indep & 5793 & 0.3720 & 5793 & 0.3710 & 0.0010 \\
Age & 5793 & 16.5000 & 5793 & 16.5700 & -0.0700 \\
Div & 5793 & 0.0080 & 5793 & 0.0080 & 0.0000 \\
Liquid & 5793 & 6.4560 & 5793 & 6.4360 & 0.0200 \\
BTM & 5793 & 0.4070 & 5793 & 0.4100 & -0.0030 \\
\hline & Dummy_Top_FH $H=1$ & Dummy_Top_FH & \\
Panel B & G2(1) & Mean2 & G1(0) & Mean1 & MeanDiff \\
\cline { 2 - 6 } & 5818 & 0.2180 & 5818 & 0.1990 & $0.0190 * * *$ \\
PDERI & 5818 & 12.7400 & 5818 & 12.7700 & -0.0300 \\
Size & 5818 & 0.2130 & 5818 & 0.2170 & -0.0040 \\
Lev & 5818 & 0.0500 & 5818 & 0.0510 & -0.0010 \\
Roa & 5818 & 0.0470 & 5818 & 0.0470 & 0.0000 \\
Loss & 5818 & 0.2220 & 5818 & 0.2280 & -0.0060 \\
Growth & 5818 & 0.2330 & 5818 & 0.2300 & 0.0030 \\
Dual & 5818 & 0.3510 & 5818 & 0.3510 & 0.0000 \\
Top1 & 5818 & 2.2580 & 5818 & 2.2600 & -0.0020 \\
Board & 5818 & 0.3720 & 5818 & 0.3710 & 0.0010 \\
Indep & 5818 & 16.4500 & 5818 & 16.4100 & 0.0400 \\
Age & 5818 & 0.0080 & 5818 & 0.0080 & 0.0000 \\
Div & 5818 & 6.5010 & 5818 & 6.4690 & 0.0320 \\
Liquid & 5818 & 0.4020 & 5818 & 0.4010 & 0.0010 \\
BTM & & & &
\end{tabular}

Results of re-regression using the matched samples appear in Table 11. Coefficients of Total_FH (1.7585) and Top_FH (2.7695) with PDERI are significant at $1 \%$ and $10 \%$, respectively. The greater the proportions of outstanding shares held by mutual funds and by leading mutual funds, the more likely sampled firms were to disclose environmental responsibility during the period 2007-2019. Evidence again implies the effect of mutual fund activism on environmental disclosure. Hypotheses 1 and 2 remain valid.

Table 11. PSM sample paired test results.

\begin{tabular}{|c|c|c|}
\hline & (1) & (2) \\
\hline & PDERI & PDERI \\
\hline Total_FH & $\begin{array}{c}1.7585^{* * *} \\
(3.1897)\end{array}$ & \\
\hline Top_FH & & $\begin{array}{l}2.7595 * \\
(1.6687)\end{array}$ \\
\hline Size & $\begin{array}{c}0.9677^{* * *} \\
(24.6396)\end{array}$ & $\begin{array}{l}0.9888^{* * *} \\
(24.8465)\end{array}$ \\
\hline Lev & $\begin{array}{c}0.2654^{* * *} \\
(3.5639)\end{array}$ & $\begin{array}{c}0.2637^{* * *} \\
(3.4576)\end{array}$ \\
\hline Roa & $\begin{array}{l}-1.0216 * \\
(-1.6851)\end{array}$ & $\begin{array}{c}-0.8738 \\
(-1.3871)\end{array}$ \\
\hline Loss & $\begin{array}{c}-0.1305 \\
(-1.0125)\end{array}$ & $\begin{array}{c}-0.0315 \\
(-0.2440)\end{array}$ \\
\hline Growth & $\begin{array}{c}-0.0318 \\
(-0.6312)\end{array}$ & $\begin{array}{l}-0.1288 * * \\
(-2.3615)\end{array}$ \\
\hline Dual & $\begin{array}{l}-0.1571^{* *} \\
(-2.3289)\end{array}$ & $\begin{array}{c}-0.2259 * * * \\
(-3.2974)\end{array}$ \\
\hline
\end{tabular}


Table 11. Cont.

\begin{tabular}{ccc}
\hline Top1 & $0.5454^{* * *}$ & 0.2985 \\
& $(2.9356)$ & $(1.6081)$ \\
Board & $0.6506^{* * *}$ & $0.4369^{* *}$ \\
& $(3.5882)$ & $(2.4110)$ \\
Indep & 0.9135 & 0.6796 \\
& $(1.5997)$ & $(1.1856)$ \\
Age & 0.0085 & 0.0088 \\
& $(1.5461)$ & $(1.6032)$ \\
Div & $9.3108^{* * *}$ & $11.6488^{* * *}$ \\
& $(3.3954)$ & $(4.3059)$ \\
Liquid & 0.0030 & -0.0017 \\
& $(0.3991)$ & $(-0.2156)$ \\
BTM & $1.1545^{* * *}$ & $1.1869^{* * *}$ \\
& $(9.2466)$ & $(9.2921)$ \\
Year & Yes & Yes \\
Industry & Yes & Yes \\
cut1_cons & $-17.6300^{* * *}$ & $-16.7071^{* * *}$ \\
& $(-20.1609)$ & $(-20.0024)$ \\
\hline$N$ & 11,586 & 11,636 \\
pseudo $R^{2}$ & 0.195 & 0.183 \\
chi2 & $2.3 \times 10^{3}$ & $2.1 \times 10^{3}$ \\
\hline
\end{tabular}

Z statistics in parentheses. ${ }^{*} p<0.10,{ }^{* *} p<0.05,{ }^{* * *} p<0.01$.

\subsubsection{Substituting Variables}

Some companies disclose social responsibility only in their annual reports. Therefore, we reconstructed the dependent variable (PDERI) according to whether sampled firms disclosed environmental responsibility in their annual reports. If a sampled firm did so, N_PDERI = 1 ( 0 otherwise), and we re-regressed the main effects model using that new dependent variable. Results appear in Table 12.

Table 12. Substituting dependent variables.

\begin{tabular}{ccc}
\hline & $(1)$ & $(2)$ \\
\hline Total_FH & N_PDERI & N_PDERI \\
& $0.7215^{* * *}$ & \\
Top_FH & $(2.3813)$ & $1.8050^{* *}$ \\
& & $(2.0289)$ \\
Size & $0.1441^{* * *}$ & $0.1503^{* * *}$ \\
& $(6.3969)$ & $(6.8322)$ \\
Lev & 0.0340 & 0.0354 \\
& $(0.6566)$ & $(0.6822)$ \\
Roa & $-0.8782^{* * *}$ & $-0.8143^{* *}$ \\
& $(-2.5853)$ & $(-2.4205)$ \\
Loss & -0.0009 & 0.0020 \\
& $(-0.0103)$ & $(0.0218)$ \\
Growth & 0.0096 & 0.0079 \\
& $(0.3214)$ & $(0.2671)$ \\
Dual & 0.0034 & 0.0042 \\
& $(0.0852)$ & $(0.1034)$ \\
Top1 & $0.4127^{* * *}$ & $0.3973^{* * *}$ \\
& $(3.5642)$ & $(3.4488)$ \\
Board & 0.0478 & 0.0471 \\
& $(0.4301)$ & $(0.4237)$ \\
Indep & -0.5197 & -0.5259 \\
\hline
\end{tabular}


Table 12. Cont.

\begin{tabular}{|c|c|c|}
\hline \multirow{3}{*}{ Age } & $(-1.4665)$ & $(-1.4841)$ \\
\hline & -0.0024 & -0.0027 \\
\hline & $(-0.6911)$ & $(-0.7943)$ \\
\hline \multirow[t]{2}{*}{ Div } & -1.2208 & -1.2551 \\
\hline & $(-0.6787)$ & $(-0.6978)$ \\
\hline \multirow{2}{*}{ Liquid } & $0.0098^{* *}$ & $0.0094^{* *}$ \\
\hline & $(2.2494)$ & $(2.1517)$ \\
\hline \multirow[t]{2}{*}{ BTM } & $0.2549^{* * *}$ & $0.2441^{* * *}$ \\
\hline & $(2.7988)$ & $(2.6920)$ \\
\hline Year & Yes & Yes \\
\hline Industry & Yes & Yes \\
\hline \multirow[t]{2}{*}{ cut1_cons } & 0.0971 & 0.0491 \\
\hline & $(0.2047)$ & $(0.1039)$ \\
\hline$N$ & 25,188 & 25,188 \\
\hline pseudo $R^{2}$ & 0.161 & 0.160 \\
\hline chi2 & $4.5 \times 10^{3}$ & $4.5 \times 10^{3}$ \\
\hline
\end{tabular}

Coefficients of Total_FH (0.7215) and Top_FH (1.8050) with N_PDERI are significant at $5 \%$. The greater the proportion of outstanding shares held by institutional investors such as funds, and by leading funds, the more likely sampled companies were to disclose environmental responsibility information in social responsibility reports during the period 2007-2019. Results again imply evidence of mutual fund activism. Hypotheses 1 and 2 remain valid.

\section{Conclusions}

Drawing 25,188 annual firm-year observations for A-share listed companies on two Chinese stock exchanges spanning the period 2007-2019, this study examined the correlation between stock ownership by mutual funds and corporate disclosure of environmental responsibility. Two findings emerged. First, the greater the proportion of outstanding shares held by mutual funds, the more likely the sampled Chinese firms were to disclose information concerning environmental responsibility. Second, the greater the proportion of listed shares held by leading mutual fund companies, the more likely sampled firms were to disclose environmental responsibility information. These results imply that mutual fund activism influenced the sampled firms toward such disclosures during the period 2007-2019. We separately found that mutual funds might exercise that same influence on companies without a security analyst and on China's publicly traded SOEs. Results also suggest that mutual funds exercised functions that were later brought about by the national enactment of new environmental protections. All hypotheses remained confirmed after a series of robustness tests. Future research can explore if mutual fund holdings will prompt listed companies to respond to the public's concerns in relation to carbon dioxide emissions and carbon neutrality.

The research findings of this paper, in theory, not only enrich the research literature on the economic consequences of mutual funds practicing shareholder activism but also enrich the research literature on the factors affecting the environmental responsibility information disclosure of listed companies. In practice, there are two-point implications to policymakers: on the one hand, to clear up the legal barriers for mutual funds to participate in the governance of listed companies as soon as possible, so as to better play the role of mutual funds in supervising listed companies, and on the other hand, they are encouraged to strengthen information disclosure supervision and urge listed companies to respond promptly to public concerns regarding environmental incidents. 
Author Contributions: Concept, Y.L. and L.L.; method, Y.L. and L.L.; software, Y.L.; validation, Y.L., L.L. and S.L.; formal analysis, Y.L.; data curation, Y.L.; original draft of document, Y.L.; review and editing, L.L.; supervision, S.L.; project administration, S.L.; funding acquisition, S.L. All authors have read and agreed to the published version of the manuscript.

Funding: This work was supported by the National Natural Science Foundation of China (Grant Nos. 71832006; 71872081; 71372030); the MOE Project of Key Research Institute of Humanities and Social Sciences at Universities (No. CYD-2020009); Talent Introduction Scientific Research Launch Project of Guizhou University of Finance and Economics (2021YJ038); and Nanjing University.

Data Availability Statement: Not applicable.

Acknowledgments: The authors thank the National Natural Science Foundation of China, the Ministry of Education of China, and Nanjing University for support.

Conflicts of Interest: The authors declare no conflict of interest.

\section{References}

1. Chen, X.; Harford, J.; Li, K. Monitoring: Which institutions matter? J. Financ. Econ. 2007, 86, 279-305. [CrossRef]

2. Firth, M.; Gao, J.; Shen, J.; Zhang, Y. Institutional stock ownership and firms' cash dividend policies: Evidence from China. J. Bank. Financ. 2016, 65, 91-107. [CrossRef]

3. Cox, P.; Wicks, P.G. Institutional Interest in Corporate Responsibility: Portfolio Evidence and Ethical Explanation. J. Bus. Ethics 2011, 103, 143-165. [CrossRef]

4. Njah, M.; Jarboui, A. Institutional investors, corporate governance, and earnings management around merger: Evidence from French absorbing firms. J. Econ. Financ. Adm. Sci. 2013, 18, 89-96. [CrossRef]

5. Henry, E.; Jiang, X.; Rozario, A. The Evolution of Environmental Discourse: Evidence from Conference Calls. Working Paper. 2021. Available online: https:/ / papers.ssrn.com/sol3/papers.cfm?abstract_id=3863354 (accessed on 28 July 2021).

6. Meek, G.K.; Roberts, C.B.; Gray, S.J. Factors Influencing Voluntary Annual Report Disclosures by U.S., U.K. and Continental European Multinational Corporations. J. Int. Bus. Stud. 1995, 26, 555-572. [CrossRef]

7. Porter, M.; Kramer, M. Creating Shared Value: How to Reinvent Capitalism-and Unleash a Wave of Innovation and Growth. Harv. Bus. Rev. 2011, 89, 62-77.

8. Lang, M.; Lundholm, R. Russell Cross-Sectional Determinants of Analyst Ratings of Corporate Disclosures. J. Account. Res. 1993, 31, 246-271. [CrossRef]

9. Park, J.; Sani, J.; Shroff, N.; White, H. Disclosure incentives when competing firms have common ownership. J. Account. Econ. 2019, 67, 387-415. [CrossRef]

10. Darnall, N.; Henriques, I.; Sadorsky, P. Adopting Proactive Environmental Strategy: The Influence of Stakeholders and Firm Size. J. Manag. Stud. 2010, 47, 1072-1094. [CrossRef]

11. Clarkson, P.M.; Li, Y.; Richardson, G.D.; Vasvari, F.P. Revisiting the relation between environmental performance and environmental disclosure: An empirical analysis. Account. Organ. Soc. 2008, 33, 303-327. [CrossRef]

12. Liu, X.; Anbumozhi, V. Determinant Factors of Corporate Environmental Information Disclosure: An Empirical Study of Chinese Listed Companies. J. Clean Prod. 2009, 17, 593-600. [CrossRef]

13. Zeng, S.X.; Xu, X.D.; Yin, H.T.; Tam, C.M. Factors that Drive Chinese Listed Companies in Voluntary Disclosure of Environmental Information. J. Bus. Ethics 2012, 109, 309-321. [CrossRef]

14. Gray, R.; Javad, M.; Power, D.M.; Sinclair, C.D. Social and Environmental Disclosure and Corporate Characteristics: A Research Note and Extension. J. Bus. Finan. Account. 2001, 28, 327-356. [CrossRef]

15. Boesso, G.; Kumar, K. Drivers of corporate voluntary disclosure: A framework and empirical evidence from Italy and the United States. Account. Audit. Acc. 2007, 20, 269-296. [CrossRef]

16. Kock, C.J.; Santalo, J.; Diestre, L. Corporate Governance and the Environment: What Type of Governance Creates Greener Companies? J. Manag. Stud. 2012, 49, 492-514. [CrossRef]

17. Kumar, S.; Sureka, R.; Lim, W.M.; Mangla, S.; Goyal, N. What do we know about business strategy and environmental research? Insights from Business Strategy and the Environment. Bus. Strateg. Environ. 2021, 1-16. [CrossRef]

18. Black, B. Shareholder Activism and Corporate Governance in the United States. New Palgrave Dict. Econ. Law 1998, 3, $459-465$.

19. Goranova, M.; Ryan, L. Shareholder Activism: A Multidisciplinary Review. J. Manag. 2013, 40, 1230-1268. [CrossRef]

20. Pound, J. Proxy voting and the SEC: Investor protection versus market efficiency. J. Financ. Econ. 1991, 29, 241-285. [CrossRef]

21. Holderness, C.; Sheehan, D. The role of majority shareholders in publicly held corporations: An exploratory analysis. J. Financ. Econ. 1988, 20, 317-346. [CrossRef]

22. Alshabibi, B. The Role of Institutional Investors in Improving Board of Director Attributes around the World. J. Risk Financ. Manag. 2021, 14, 166. [CrossRef]

23. Sakawa, H.; Watanabel, N. Institutional Ownership and Firm Performance under Stakeholder-Oriented Corporate Governance. Sustainability 2020, 12, 1021. [CrossRef] 
24. Morck, R.; Shleifer, A.; Vishny, R.W. Management ownership and market valuation: An empirical analysis. J. Financ. Econ. 1988, 20, 293-315. [CrossRef]

25. DAVID, P.; Hillman, B. Investor activism, managerial responsiveness, and corporate social performance. Strateg. Manag. J. 2010, 28, 91-100. [CrossRef]

26. Ullmann, A.A. Data in Search of a Theory A Critical Examination of the Relationships Among Social Performance, Social Disclosure, and Economic Performance of U.S. Firms. Acad. Manag. Rev. 1985, 10, 540-557.

27. Roberts, C. Environmental disclosures in corporate annual reports in Western Europe. In Green Reporting: Accountancy and the Challenge of the Nineties; Chapman \& Hall: London, UK, 1992; pp. 139-165.

28. Renneboog, L.; Horst, J.T.; Zhang, C. Is ethical money financially smart? Nonfinancial attributes and money flows of socially responsible investment funds. J. Financ. Intermed. 2011, 20, 562-588. [CrossRef]

29. Chung, H.; Talaulicar, T. Forms and Effects of Shareholder Activism. Corp. Gov. 2010, 18, 253-257. [CrossRef]

30. Petersen, H.L.; Vredenburg, H. Morals or Economics? Institutional Investor Preferences for Corporate Social Responsibility. J. Bus. Ethics 2009, 90, 1. [CrossRef]

31. Pucheta-Martínez, M.C.; García-Meca, E. Institutional Investors on Boards and Audit Committees and Their Effects on Financial Reporting Quality. Corp. Gov. An. Int. Rev. 2014, 22, 347-363. [CrossRef]

32. Fombrun, C.; Shanley, M. What's in a Name? Reputation Building and Corporate Strategy. Acad Manag. J. 1990, 33, $233-258$.

33. Minor, D.; Morgan, J. CSR as Reputation Insurance: Primum Non Nocere. Calif. Manag. Rev. 2011, 53, 40-59. [CrossRef]

34. Alexander, D.; Lins, K.V.; Lukas, R.; Wagner, H.F. Do institutional investors drive corporate social responsibility? International evidence. J. Financ. Econ. 2018, 131, 693-714.

35. Shleifer, A.; Vishny, R.W. Large Shareholders and Corporate Control. J. Political Econ. 1986, 94, 461-488. [CrossRef]

36. Agrawal, A.; Knoeber, C. Firm Performance and Mechanisms to Control Agency Problems between Managers and Shareholders. J. Financ. Quant. Anal. 1996, 31,377-397. [CrossRef]

37. Parrino, R.; Sias, R.W.; Starks, L.T. Voting with their feet: Institutional ownership changes around forced CEO turnover. J. Financ. Econ. 2003, 68, 3-46. [CrossRef]

38. Schnatterly, K.; Shaw, K.W.; Jennings, W.W. Information advantages of large institutional owners. Strateg. Manag. J. 2008, 29, 219-227. [CrossRef]

39. Akins, B.; Ng, J.; Verdi, R. Investor Competition Over Information and the Pricing of Information Asymmetry. Account. Rev. 2011, 87, 35-58. [CrossRef]

40. Hope, O.; Wu, H.; Zhao, W. Blockholder exit threats in the presence of private benefits of control. Rev. Account. Stud. 2017, 22, 873-902. [CrossRef]

41. Clarkson, P.; Ponn, J.; Richardson, G.D.; Rudzicz, F.; Tsang, A.; Wang, J. A Textual Analysis of U.S. Corporate Social Responsibility Reports. Working Paper. 2018. Available online: https:/ / papers.ssrn.com/sol3/papers.cfm?abstract_id=3102627 (accessed on 28 July 2021).

42. David, P.; Kochhar, R. Barriers to effective corporate governance by institutional investors: Implications for theory and practice. Eur. Manag. J. 1996, 14, 457-466. [CrossRef]

43. Wang, A.W.; Zhang, G. Institutional ownership and credit spreads: An information asymmetry perspective. J. Empir. Financ. 2009, 16, 597-612. [CrossRef]

44. Gisbert, A.; Navallas, B. The association between voluntary disclosure and corporate governance in the presence of severe agency conflicts. Adv. Account. 2013, 29, 286-298. [CrossRef]

45. Cheng, E.C.M.; Courtenay, S.M. Board composition, regulatory regime and voluntary disclosure. Int. J. Account. 2006, 41, 262-289. [CrossRef]

46. Chau, G.K.; Gray, S.J. Ownership structure and corporate voluntary disclosure in Hong Kong and Singapore. Int. J. Account. 2002, 37, 247-265. [CrossRef]

47. Huang, C.; Kung, F. Drivers of Environmental Disclosure and Stakeholder Expectation: Evidence from Taiwan. J. Bus. Ethics 2010, 96, 435-451. [CrossRef]

48. D'Amico, E.; Coluccia, D.; Fontana, S.; Solimene, S. Factors Influencing Corporate Environmental Disclosure. Bus. Strateg. Environ. 2016, 25, 178-192. [CrossRef] 